\title{
The importance of COX-2 inhibition for aspirin induced asthma
}

\author{
Alan Bennett
}

There have been recent reviews of aspirin induced asthma (AIA), ${ }^{12}$ the use of the COX-2 preferential inhibitor nimesulide in asthmatic patients intolerant to non-steroidal anti-inflammatory drugs (NSAIDs), ${ }^{3}$ and of nimesulide in general. ${ }^{45}$ This paper discusses the importance of inhibiting prostaglandin $\mathrm{E}_{2}$ $\left(\mathrm{PGE}_{2}\right)$ synthesis in $\mathrm{AIA}$, and the relative safety of NSAIDs that preferentially inhibit COX-2.

Aspirin and other NSAIDs cause bronchoconstriction in about $10 \%$ of asthmatic subjects but NSAIDs relieve asthma in about $0.3 \%$. $^{2}$ This variability helps to show the complexity of the problem. Prostaglandins in human lung are formed by various tissues and cells, including bronchial muscle, epithelium, and inflammatory cells, ${ }^{12}$ so the inhibition of prostaglandin formation can have numerous effects. In addition, the prostanoids (prostaglandins and thromboxanes) formed have different, and sometimes opposite, effects on the lungs. Furthermore, NSAIDs may alter the synthesis of various prostaglandins differently in patients with AIA - for example, aspirin reduces the synthesis of $\mathrm{PGE}_{2}$ but not of the bronchoconstrictors $\mathrm{PGD}_{2}$ and $\mathrm{PGF}_{2 \alpha}{ }^{6}$ Inhibition of $\mathrm{PGE}_{2}$ synthesis seems to be particularly important in AIA for several reasons: $\mathrm{PGE}_{2}$ can relax bronchial muscle, inhibit the formation or release of various bronchoconstrictor agents such as leukotrienes and histamine (levels of which are raised in patients with $\mathrm{AIA}$ ), and $\mathrm{PGE}_{2}$ administered as an aerosol inhibits aspirin induced bronchoconstriction. ${ }^{12}$

Since $\mathrm{PGE}_{2}$ and other prostanoids are formed by both constitutive COX-1 and induced COX-2, the effect on the lung may partly reflect the relative activities of each NSAID on the enzymes. Generally, in various tissues and organs such as the gastrointestinal mucosa and kidney, COX-1 produces prostaglandins that have physiological protective roles, whereas COX-2 induced at sites of inflammation forms prostaglandins that contribute to the disease. It is generally agreed that blocking COX-1 can damage the stomach and kidneys, at least when other factors are involved, and perhaps this applies to the lungs.

Academic Department of Surgery, The Rayne Institute, Guy's, King's and St Thomas' Medical School, London SE5 9NU, UK A Bennett

Correspondence to: Professor A Bennett abenn@cwcom.net

\section{COX-2/COX-1 inhibition in relation to \\ AIA}

Examination of the relative importance of COX enzymes in AIA can be partly assessed from studies using preferential COX-2 inhibitors. The term "preferential" is used here to denote activity that is somewhat greater against COX-2 than against COX-1, whereas the term "specific" is used here to denote that the activity is (usually) much greater against COX-2 than against COX-1. Two drugs with a "preferential" status are nimesulide and meloxicam, whereas two drugs that probably deserve the title "specific" are rofecoxib and celecoxib.

Nimesulide (4-nitro-2-phenoxymethanesulphonanilide) is particularly important in AIA because several studies have shown that it is tolerated by most patients with the disorder to about the same extent as paracetamol. This sulphonanilide NSAID, which is effective in treating a wide spectrum of inflammatory and painful conditions, ${ }^{7}$ was first marketed in 1985 and 10 years later it was found to be a preferential inhibitor of COX-2. ${ }^{89}$ Because it is not marketed in the USA, Japan, or the UK, nimesulide is not well known in some parts of the world. Nevertheless, in the 50 countries where it is now sold, nimesulide is often the first or second NSAID in the local market, and it is fifth worldwide despite being absent from the largest markets.

In every study of COX selectivity nimesulide was more potent against COX-2 than COX-1. However, as with all NSAIDs, its COX-1/ COX-2 ratio varies in different reports (from about 4.5 to 2500 in favour of COX-2). ${ }^{9}$ Factors influencing the ratio include the enzyme source, cell type, substrate concentration, and incubation time.

Our own investigations were on COX-1 and COX-2 sheep pure enzymes, and human gastric mucosa (constitutive COX-1) and leucocytes (induced COX-2). ${ }^{8}$ We found that COX-1 from sheep seminal vesicles was not inhibited by nimesulide, in contrast to the concentration-related inhibition by indomethacin, naproxen, piroxicam, ibuprofen, tolmetin, and diclofenac. COX-2 from sheep placenta was blocked by all the NSAIDs. In our human in vitro studies nimesulide blocked COX-2 in leucocytes, but only weakly inhibited COX-1 in isolated gastric mucosa. Similarly, with human subjects nimesulide inhibited leucocyte COX-2 to a considerable extent but had little effect on COX-1 in the gastric mucosa and platelets. $^{10}$

\section{Nimesulide}

Since nimesulide was initially thought to act mainly by non-prostaglandin mechanisms (before it was realised that tissue containing COX-1 was used to measure inhibition of prostaglandin synthesis ${ }^{11}$ ), nimesulide was tested in patients who could not tolerate other NSAIDs. The studies summarised in table 1 show that nimesulide can be tolerated by most patients with AIA. It can usually 
Table 1 Tolerance data on nimesulide in AIA

\begin{tabular}{lll}
\hline Nimesulide dose (mg) & $\begin{array}{l}\text { Patients tolerating } \\
\text { nimesulide (\%) }\end{array}$ & Reference \\
\hline 100 & $20 / 20(100 \%)$ & 12 \\
100 & $20 / 20(100 \%)$ & 13 \\
400 & $18 / 20(90 \%)$ & 13 \\
200 & $46 / 50(92 \%)$ & 14 \\
100 & $7 / 12(58 \%)$ & 15 \\
\hline
\end{tabular}

Nimesulide was started at a low dose and then increased to the amount shown. The usual anti-inflammatory dose is $100 \mathrm{mg}$ twice daily. In the study by Bianco et $\mathrm{l}^{13}$ the 20 patients were the same in the $100 \mathrm{mg}$ and $400 \mathrm{mg}$ groups.

Table 2 Tolerance data on nimesulide in patients with other symptoms of NSAID intolerance

\begin{tabular}{lll}
\hline Nimesulide dose (mg) & $\begin{array}{l}\text { Patients tolerating } \\
\text { nimesulide (\%) }\end{array}$ & Reference \\
\hline 500 (over 84 h) & $86 / 92(93 \%)$ & 16 \\
200 & $39 / 42(93 \%)$ & 17 \\
100 & $270 / 284(95 \%)$ & 18 \\
200 & $83 / 87(95 \%)$ & 19 \\
200 & $415 / 429(97 \%)$ & 20 \\
175 & $14 / 15(93 \%)$ & 21 \\
100 & $7 / 8(88 \%)$ & 15 \\
\hline
\end{tabular}

Nimesulide was started at a low dose and then increased to the amount shown. The usual anti-inflammatory dose is $100 \mathrm{mg}$ twice daily. Symptoms in the few patients showing some intolerance to nimesulide were often mild.

be given without any problems to patients with other symptoms of NSAID intolerance such as urticaria and/or angio-oedema (table 2).

\section{Meloxicam}

Only one small study has been reported on the use of meloxicam in patients with AIA. In five NSAID intolerant patients dyspnoea occurred in two with aspirin and two with ketoprofen, but three of these four had no dyspnoea with $11 \mathrm{mg}$ meloxicam (therapeutic dose 7.5$15 \mathrm{mg}$ daily). ${ }^{22}$

\section{Celecoxib and rofecoxib}

These new selective COX-2 inhibitors have not yet been examined in AIA and are currently contraindicated in such patients. If inhibition of COX-1 is the (main) cause of AIA, the selective COX-2 inhibitors may well be safe in patients who cannot tolerate other NSAIDs. Studies with these new drugs would help to elucidate the mechanism(s) of AIA.

\section{Analysis of the current evidence that absence of COX-1 inhibition would avoid intolerance to NSAIDs}

The findings discussed above, and the clinical evidence mainly with nimesulide, are consistent with the possibility that inhibition of COX-1 is an important cause of AIA. However, nimesulide is not just a COX-2 inhibitor, as discovered partly before COX-2 was known. Other effects that occur with therapeutically relevant amounts of nimesulide include (a) inhibition of the formation of superoxide anions by neutrophils, ${ }^{23}$ (b) inhibition of histamine action and release, ${ }^{24}{ }^{25}$ (c) $\mathrm{TNF}_{\alpha}$ hyperalgesia, ${ }^{26}$ and (d) synthesis of stromelysin and collagenase (which degrade proteoglycan and collagen). ${ }^{27}$
Thus, the usual lack of bronchial problems with nimesulide in patients with AIA might result partly from these other pharmacological actions. Meloxicam has also been reported to have non-prostaglandin activity and this might become relevant to the present discussion if the drug is found in larger studies to be relatively safe in AIA. The picture should be clarified in due course by examination of the selective COX-2 inhibitors rofecoxib and celecoxib. It remains to be seen how much COX-1 activity is needed to allow production of prostaglandins for physiological functions, and whether a small inhibition of COX-1 added to a stronger effect on COX-2 might be beneficial in relieving inflammatory processes that contribute to asthma and other diseases.

1 Szczeklik A, Stevenson DD. Aspirin-induced asthma: advances in pathogenesis and management. F Allergy Clin Immunol 1999;104:5-13.

2 Gryglewski RJ. Aspirin-induced asthma and cyclooxygenases. In: Vane J, Botting J, eds. Selective COX-2 inhibitors. Pharmacology, clinical effects and therapeutic potential. William Harvey Press and Kluwer Academic Publishers, 1998: 99-107.

3 Senna GE, Passalacqua G, Andri G, et al. Nimesulide in the reatment of patients intolerant of aspirin and other NSAIDs. Drug Safety 1996;14:94-103.

4 Bennett A. Overview of nimesulide. Rheumatology 1999; 38(Suppl 1): $1-3$.

5 Bennett A, Villa G. Nimesulide: a nonsteroidal antiinflammatory drug that preferentially inhibits cyclooxygenase-2, and has various unique pharmacological activities. Expert Opinion on Pharmacotherapy 2000;1:27786.

6 Szczeklik A, Sladek K, Dworski R, et al. Bronchial aspirin challenge causes specific eicosanoid response in aspirinsensitive asthmatics. Am f Respir Crit Care Med 1996;154: 1608-14.

7 Bennett A, Berti F, Ferreira SH. Nimesulide: a multifactorial therapeutic approach to the inflammatory process? Drugs 1993;46 (Suppl 1).

8 Tavares IA, Bishai PM, Bennett A, Activity of nimesulide on constitutive and inducible cyclo-oxygenases. ArzneimittelForschung 1995;45:1093-6.

9 Famaey J-P. In vitro and in vivo pharmacological evidence of Famaey J-P. In vitro and in vivo pharmacological evidence of
selective cyclooxygenase-2 inhibition by nimesulide: an overview. Inflamm Res 1997;46:437-46.

10 Shah AA, Murray FE, Fitzgerald DJ. The in vivo assessment of nimesulide cyclooxygenase-2 selectivity. Rheumatology 1999;38(Suppl 1):19-23.

11 Magni E. The effect of nimesulide on prostanoid formation. Drugs 1993;46(Suppl 1):10-14.

12 Robuschi M, Refini M, Sturman et al. La nimesulide non induce asma in pazienti asmatici FANS intolleranti. Proceedings of an International Symposium on Advances in Pneumology and Cardiology. Bologna: Monduzzi Publishers, 1987: 431-5.

13 Bianco S, Robuschi M, Petrigni G et al. Efficacy and tolerability of nimesulide in asthmatic patients intolerant to aspirin. Drugs 1993;46 (Suppl 1):115-20.

14 Bilancia R, Ferranini A, Chianese R, et al. Nimesulide tolerance in ASA-induced asthma. In: Basomba A, Sastre J, eds. Proceedings of XVI European Congress of Allergology and Proceedings of XVI European Congress of Allergology and Clinical Im

15 Faria E, Tomas MR, Carrapatoso JA, et al. Could nimesulide be an alternative in aspirin hypersensitivity patients? Allergy 1996;51 (Suppl 31):57

16 Astarita C, Franzese A, Sproviero S, et al. Epidemiologia delle reazioni avverse ai farmaci antiifiammatori non steroidei. $\mathrm{La}$ nimesulide e tollerata dai pazienti con reazioni avverse ai FANS e modula nell'uomo la riposta cutanea all'istamina ed alla codeina. Recenti Prog Med 1992;83:567-71.

17 Muratore L, Ferraranini A, Toraldo MD, et al. Studio controllato sulla tollerabilita della nimesulide in pazenti con
manifestazioni cutanee da intolleranza ad ASA e FANS. $G$ Ital Allergol Immunol Clin 1992;2:157-62.

18 Ispano M, Fontana A, Scibilia J, et al. Oral challenge with alternative non steroidal antiinflammatory drugs and paracetamol in patients intolerant to these agents. Drugs 1993; 46(Suppl 1):253-6.

19 Andri L, Senna GE, Andri G, et al. Impiego della nimesulide in soggetti con intolleranza agli antiinfiammatori non sterin soggetti con intolleranza agli antiinfiammato
oidi. Folia Allergol Immunol Clin 1990;37:93-7.

20 Andri L, Senna GE, Betelli C, et al. Tolerability of nimesulide in aspirin sensitive patients. Ann Allergy 1994;72:29-32.

21 Bernstein $M$, Rodriguez C. Challenge with nimesulide, a new NSAID, in patients with reactions to aspirin and other NSAIDs (abstract). F Allergy Clin Immunol 1996;97:345. 
22 Kosnik M, Music E, Matjaz F, et al. Relative safety of meloxicam in NSAID-intolerant patients. Allergy 1998;53:1231-3. 23 Ottonello L, Dapino P, Pastorino G, et al. Inhibition of the neutrophil oxidative response induced by the oral administration of nimesulide in normal volunteers. $\mathcal{f}$ Clin Lab Immunol 1992;37:91-6.

24 Berti F, Rossoni G, Buschi A, et al. Antianaphylactic and antihistaminic activity of the non-steroidal anti-inflammatory compound nimesulide in guinea-pig. Arzneimittel-Forschung 1990;40:1011-6.
25 Rossoni G, Berti F, Buschi A, et al. New data concerning the antianaphylactic and antihistaminic activity of nimesulide. Drugs 1993;46(Suppl 1):22-8.

26 Ferreira SH. The role of interleukins and nitric oxide in the mediation of inflammatory pain and its control by peripheral analgesics. Drugs 1993; 46(Suppl 1):1-9.

27 Pelletier JP, Martel-Pelletier J. Effects of nimesulide and naproxen on the degradation and metalloprotease synthesis of human osteoarthritic cartilage. Drugs 1993;46(Suppl 1):34-9. 